\title{
Dzicy i tropiki, czyli transfer kulturowy w polskich tekstach dla teatru*
}

Transkulturowość istnieje nie tylko na makropoziomie całych społeczności, ale sięga też mikropoziomu tożsamości indywidualnej ${ }^{1}$.

Wolfgang Welsch

W polskiej literaturze dramatycznej ostatniego ćwierćwiecza pojawiło się sporo tekstów, które odzwierciedlają proces przemian społeczno-kulturowych przełomu stuleci i podważają obowiązujące jeszcze w XX wieku modele funkcjonowania starego europejskiego świata i paradygmaty poznawcze Europejczyka. Jeśli chodzi o rodzimą twórczość dramatyczną ostatnich dwudziestu pięciu lat, to można wyróżnić w niej przynajmniej trzy główne obszary tematyczne i problemowe - ściśle związane ze zmianą w życiu Polaków, którzy najpierw boleśnie doświadczyli realiów postkomunistycznego kraju, a potem zmierzyć się musieli z koniecznością funkcjonowania w rzeczywistości wolnorynkowej, w coraz bardziej „kurczącym się” świecie nowych technologii. Twórczość dramatopisarska poświęcona wspomnianym zagadnieniom rozpoczęła się dość skromnie pod względem literackim - od różnych prób obrazowania nowych zjawisk i konfliktów społecznych, wynikających ze zmian ustrojowych, co zaowocowało pokaźnym zbiorem tekstów społeczno-obyczajowych, raczej doraźnych, zbudowanych z użyciem konwencji reportażowej, rejestrujących różne dysfunkcje i anomalie współczesnego życia rodzinnego. Po kilkuletnim okresie „zainfekowania” teraźniejszością, co w sposób zupełnie zrozumiały tłumaczyć można potrzebą rozpoznania i utrwalenia nowej, jakże odmiennej od czasów PRL-u, codzienności

* Niniejszy artykuł jest przeredagowaną i poszerzoną wersją referatu wygłoszonego na konferencji naukowej Przestrzenie kultury. Horyzonty historyczne, teoretyczne, metodologiczne, zorganizowanej przez Instytut Nauk o Kulturze i Studiów Interdyscyplinarnych na Wydziale Filologicznym Uniwersytetu Śląskiego w Katowicach 8 grudnia 2017 r.

1. Wolfgang Welsch, Tożsamo w epoce globalizacji - perspektywa transkulturowa, w: Estetyka transkulturowa, red. Krystyna Wilkoszewska, Wydawnictwo Universitas, Kraków 2004, s. 34. 
i potoczności, autorzy utworów dramatycznych zwrócili się w stronę zdarzeń historycznych, podejmując nie tylko bardzo skuteczne akty rozliczenia z wojenną i komunistyczną przeszłością, ale także literackie próby oświetlania minionych faktów w perspektywie postpamięci. Wzrosło zatem zainteresowanie tematami tabu, wzbudzającymi radykalne podziały wśród czytelników i widzów teatralnych - przede wszystkim z tego względu, że wielu autorów podważyło społeczne mity bohaterstwa i ofiarnictwa Polaków. Ewidentnym przykładem potwierdzającym znaczenie tego nurtu we współczesnej twórczości pisarskiej było przyznanie Nagrody Literackiej Nike w 2010 roku Tadeuszowi Słobodziankowi za dramat Nasza klasa, nawiązujący do wydarzeń w Jedwabnem. I wreszcie - last but not least - w najnowszej twórczości dramatyczno-teatralnej wskazać można grupę tekstów, które ujmują egzystencję współczesnego człowieka w znacznie szerszej perspektywie - stanowią świadectwo istnienia płynnych, dynamicznych „stref kontaktu" między tym, co lokalne i globalne, narodowe i światowe, swojskie i obce. Mam na myśli sztuki eksponujące problem mobilności kulturowej, bo ich autorzy, ukazując sieć wzajemnych połączeń i uwarunkowań między różnymi kulturami, zwrócili szczególną uwagę „tak na jawne, jak ukryte przemieszczanie się ludzi, przedmiotów, obrazów, tekstów i idei”2.

Symptomatycznym zjawiskiem w obszarze polskiej twórczości dramatopisarskiej jest to, że na początku drugiej dekady XXI wieku powstało w krótkim odstępie czasu kilka utworów scenicznych poświęconych problematyce konfrontacji Europejczyka z przedstawicielami innych, pozaeuropejskich kultur. Autorzy tekstów i spektakli teatralnych skupili uwagę na reprezentowaniu Inności, dramatyzując w swych działaniach twórczych „odległość i różnicę pomiędzy tym, co jest [...] bliskie, a tym, co odległe”' . Utwory, o których mowa, to: Życie seksualne dzikich Marcina Cecki (2011), W pustyni i w puszczy. Z Sienkiewicza i $z$ innych Bartka Frąckowiaka i Weroniki Szczawińskiej (2011), Śmierć Kalibana Magdy Fertacz (2012) oraz Smutki tropików Mateusza Pakuły (2014). W tych kilku utworach dostrzec można podobne autorskie podejście do problematyzowania zjawiska cyrkulacji dóbr kulturowych ${ }^{4}$, to znaczy jawną grę perspektyw w relacji swojskiego $\mathrm{z}$ obcym. Twórcy teatralni są bowiem świadomi ambiwalentnej roli reprezentacji, która „z jednej strony podtrzymuje i reprodukuje dominujące dyskursy

2. Stephen Greenblatt, Manifest badań nad mobilnością kulturową, przeł. Mateusz Borowski, Małgorzata Sugiera, „Didaskalia”, 2011, nr 106, s. 47.

3. Edward Said, Orientalizm, przeł. Monika Wyrwas-Wiśniewska, Wydawnictwo „Zysk i S-ka”, Poznań 2005, s. 98.

4. Nawiązuję w tym miejscu oczywiście do poglądów Stephena Greenblatta. Zob. Stephen Greenblatt, Poetyka kulturowa. Pisma wybrane, wstęp i red. Krystyna Kujawińska-Courtney, Wydawnictwo Universitas, Kraków 2006, s. 145-156. 
tożsamości i władzy, a z drugiej zaś może stanowić czynnik transformujący lub rewolucjonizujący je" .

Obecność tematyki konfrontacji kultur w literaturze dramatycznej oraz twórczości teatralnej ma swe rozległe uwarunkowania ideowo-poznawcze i wyraźne artystyczne konsekwencje. Przyczyn tego zjawiska szukać należy przede wszystkim w rozwoju krytyki postkolonialnej oraz badań nad reprezentacjami kulturowej odmienności w różnych dyskursach naukowych, publicystycznych czy politycznych. Liczne publikacje na ten temat, przeznaczone nie tylko dla wąskiej grupy specjalistów, odgrywają niemałą rolę w budzeniu nowej wrażliwości na problem różnic etnicznych, bo ich autorzy wyraźnie przeciwstawiają się dychotomicznym podziałom na to, co Zachodnie/cywilizowane/nowoczesne i na to, co Inne/pierwotne/tradycyjne.

Potrzeba czy też konieczność konfrontacji z tym, co odmienne/obce, wynika nie tylko z rozpowszechniania naukowych idei kulturowej różnorodności i heterogeniczności współczesnego globalnego świata. Jest również konsekwencją głębokich przemian cywilizacyjnych i migracyjnych, których jesteśmy świadkami i niejako współuczestnikami jako mieszkańcy Starego Kontynentu - kontynentu, który stanowi obecnie dynamiczny obszar wędrówek i przemieszczeń uchodźców z krajów pozaeuropejskich. Dlatego też kilka polskich utworów teatralnych poświęconych skomplikowanej relacji Swoi/dalecy Inni należy postrzegać jako reakcję na szereg współczesnych czynników zewnętrznych, warunkujących światopogląd oraz praktykę życia codziennego mieszkańców Europy Środkowej. Jest to znakomity przykład twórczości warunkowanej kontekstowo, anektującej w swój obszar najbardziej palące i konfliktogenne dyskusje o charakterze zarówno społeczno-politycznym, jak i naukowym.

Zjawisko przenikania się wytworów i treści pochodzących z wielu kultur, uobecnione w polskich tekstach dla teatru oraz przedstawieniach scenicznych, analizować można w nawiązaniu do teorii transferu kulturowego. Choć przedmiotem zainteresowania badaczy transferu, zgodnie z postulatami autorów tej koncepcji - Michela Espagne’a i Michaela Wernera - są przede wszystkim „społeczne praktyki i wymiany międzykulturowe, a nie ich przedmioty"6, to warto przyjrzeć się również konkretnym produktom artystycznym, powstałym jako swego rodzaju manifestacja transkulturowości. O tym, że koncepcja transferu może być dobrym kluczem w refleksji o polskich tekstach teatralnych, świadczą okoliczności powstania i liczne własności tych utworów. A zatem kolejno: dobór

5. Eugenia Prokop-Janiec, Etnopoetyka, w: Kulturowa teoria literatury 2. Poetyki, problematyki, interpretacje, red. Teresa Walas, Ryszard Nycz, Wydawnictwo Universitas, Kraków 2012, s. 204.

6. Lena Magnone, Emisariusze Freuda. Transfer kulturowy psychoanalizy do polskich sfer inteligenckich przed II wojna światową, Wydawnictwo Universitas, t. I, Kraków 2016, s. 7. 
przedmiotów przedstawienia i jakość literackiej reprezentacji świata, waga kontekstu społeczno-historycznego, umożliwiającego pełnoprawne zaistnienie treści wcześniej $z$ różnych przyczyn nieobecnych $\mathrm{w}$ przekazach artystycznych oraz pewien rodzaj koniunktury na problematykę kolonialną ${ }^{7}$ związanej z procesem emancypacji kultur zdominowanych, z przewartościowaniem postaw europocentrycznych na rzecz innego postrzegania i definiowania obcości. O możliwości zastosowania kategorii transferu kulturowego do analizy kilku wskazanych powyżej tekstów scenicznych świadczy nie tylko tematyka tych utworów, ale również dostrzegalna w ich warstwie kompozycyjnej autorska potrzeba i gotowość do przyjęcia i przyswojenia elementów kultur obcych. Autorzy z premedytacją wykorzystują w swych przekazach różne kody kulturowe i alternatywne systemy symboliczne nie w celu porównania odmiennych kultur, ale jako punkt wyjścia refleksji o samym procesie przyswajania tego, co transferowane, o dynamice recepcji i zmianach zachodzących pod jej wpływem w kulturze przyjmującej. Nie trzeba dodawać, że jednym z nadrzędnych problemów przedstawienia artystycznego jest w takiej perspektywie kwestia tożsamości poszczególnych jednostek ukazanych $\mathrm{w}$ procesie konfrontacji z Innością.

Sztuki teatralne Marcina Cecki, Bartka Frąckowiaka i Weroniki Szczawińskiej, Magdy Fertacz i Mateusza Pakuły to utwory powstałe z namysłu nad znaczeniem kilku dzieł o doniosłej roli kulturotwórczej i znaczącej randze kulturoznawczej. Zaznaczyć bowiem należy, że autorzy utworów scenicznych, podejmujących tematykę konfrontacji odległych, znacznie różniących się od siebie kultur, nawiązali do tekstów kanonicznych, tak z obszaru literatury polskiej/europejskiej, jak i z dziedziny antropologii kultury. Refleksja nad Innością nie wynika zatem $\mathrm{z}$ bezpośredniego doświadczenia kontaktu z przedstawicielami różnych społeczności tradycyjnych, ale jest efektem interpretacji tekstów gotowych, utrwalonych w naszym kręgu kulturowym jako dzieła ważne, a nawet przełomowe, poświęcone w dużej mierze relacji oświeconego Europejczyka z dzikimi osobnikami z nieznanego świata. I tak kolejno: Marcin Cecko i Krzysztof Garbaczewski za przedmiot artystycznych nawiązań obrali Życie seksualne dzikich Bronisława Malinowskiego, Bartosz Frąckowiak i Weronika Szczawińska posłużyli się w swym przedstawieniu powieścią Henryka Sienkiewicza o przygodach Stasia i Nel, Magdalena Fertacz w sztuce Śmierć Kalibana przywołała znaną z Burzy Szekspira figurę dzikiego/ odmieńca, a Mateusz Pakuła nawiązał intertekstualny dialog ze Smutkiem tropików Claude’a Lévi-Straussa. Można rzec zatem, zgodnie z teorią transferts culturels,

7. Zob. Dominik Pick, Czym jest transfer kultury? Transfer kultury a metoda porównawcza. Możliwości zastosowania transferts culturels na gruncie polskim, w: Monolog - dialog - transfer. Relacje kultury polskiej i niemieckiej w XIX i XX wieku, red. Mirosława Zielińska, Marek Zybura, Wydawnictwo GAJT, Wrocław 2013, s. 255-256. 
że głównym przedmiotem zainteresowania i przedstawienia są dla wspomnianych autorów „aktorzy transferu kultury” ${ }^{8}$, to znaczy podróżnicy/migranci/badacze i pozostawione przez nich pisemne świadectwa kontaktu z ludnością terytoriów odległych od cywilizacji europejskiej. Tytuły i problematyka tekstów scenicznych sugerują ponadto, że warto odbierać je i interpretować co najmniej dwuaspektowo. Po pierwsze, w myśl założeń etnopoetyki, której przedmiotem zainteresowania są „środki, konwencje, strategie i praktyki literatury opowiadającej o odmienności, inności, obcości kulturowej"9. Po drugie, jako przykłady przepisywania i recyclingu wcześniejszych, uznanych form artystycznych, dzięki czemu twórcom łatwo nawiązać szybkie i wielopoziomowe porozumienie z publicznością ${ }^{10}$.

Gdyby ogólnie ująć znaczenia kilku etnograficznie zorientowanych polskich tekstów teatralnych, to można by wyróżnić w nich szereg znanych motywów literatury, sztuki i pisarstwa antropologicznego, w których przedmiotem refleksji bywa zarówno odmienność opisywanych kultur, jak i sam mechanizm postrzegania/konstruowania tego, co inne. Spośród nadrzędnych, powtarzających się motywów, obecnych w tego typu pisarstwie, wymienić należy: pasję poznawczą Europejczyka, który z pełnym poświęceniem doświadcza kontaktu z Innymi, także z myślą o głębszym samopoznaniu; pragnienie ucieczki z cywilizowanego, wrogiego świata do natury, w rejony dzikiej przyrody i pierwotnych instynktów człowieka; topos wysp szczęśliwych, gdzie odzyskać można równowagę wewnętrzną i poczucie radości życia, a także - vice versa - misję uczłowieczania nieoświeconych plemion zgodnie z etnocentrycznym przekonaniem o wyższości białego człowieka nad ludźmi o innym kolorze skóry. Wszystkie te motywy pojawiają się w tekstach pisanych dla sceny bądź w sposób marginalny, w tle dominującej problematyki, bądź też jako przedmiot demonstracyjnych przywołań/przekształceń. Osoby piszące współcześnie dla teatru nie mają bowiem najmniejszych wątpliwości, że każda reprezentacja ma walor konstrukcji tego, co przedstawiane i wzmacniają swój przekaz, stosując różne formy pogłębiania dystansu wobec świata fikcyjnego. Tym samym dla zrozumienia i w pewnym sensie zaakceptowania różnych współczesnych, hybrydycznych przekazów werbalnych, tworzonych z przeznaczeniem dla sceny, przydatne okazuje się przekonanie, że:

„obcość" jest konstruowana i komunikowana w historycznych, kulturowych, społecznych, ideologicznych kontekstach, jej reprezentacje zaś są częścią dynamicznego procesu

8. Zob. Pick, Czym jest transfer kultury?..., s. 257.

9. Prokop-Janiec, Etnopoetyka..., s. 187. Zob. również: Bernhard Waldenfels, Podstawowe motywy fenomenologii obcego, przeł. Janusz Sidorek, Warszawa 2009, s. 110-111.

10. Zob. Słownik pojęć dramaturgicznych, w: Zawód: dramaturg, „Notatnik Teatralny” 2010, nr 58-59, s. 85-89. 
„produkcji, zawłaszczenia, kolekcjonowania i wystawiania na pokaz tekstów pisanych, obrazów plastycznych i przedmiotów materialnych"11.

Konstruktywny aspekt literackich reprezentacji różnic kulturowych łączy się z ujawnianiem perspektywy opisu, czyli ze strategią uwydatniania punktu widzenia twórcy werbalnego przekazu ${ }^{12}$. W omawianych tekstach teatralnych nie ma autorskich ujęć totalizujących i monologicznych. Ale kategorię punktu widzenia można $\mathrm{z}$ powodzeniem wykorzystać $\mathrm{w}$ analizie tych sztuk ze względu na charakterystyczne dla nich autorskie zabiegi eksponowania dominujących (kulturowych i ideowych) uwarunkowań określonej wypowiedzi dramatycznej, przy jednoczesnym włączeniu w ramy przekazu kilku innych możliwych perspektyw oglądu świata. Dzięki temu powstały utwory programowo niejednorodne, zmuszające odbiorcę do namysłu nad zdynamizowaną, pełną spięć i opozycji, wewnętrzną logiką tekstu. Utwory te cechuje spory potencjał dramaturgiczny i znaczne zróżnicowanie w zakresie technik kompozycyjnych. Pomimo wielu podobnych nawiązań do ogranych motywów reprezentacji kultury dalekich Innych, pomimo powtarzającej się strategii kompilacji różnorodnego tworzywa językowego w większe całostki tekstowe, każdy z autorów podejmujących problem konfliktów etnicznych, zaprojektował oryginalną, w pełni zindywidualizowaną wypowiedź na temat transferowania różnych dóbr kultury i związanego z tym napięcia „między indywidualnym podmiotem a ograniczeniami strukturalnymi”"13.

Trzy spośród wspomnianych przeze mnie tekstów teatralnych ukazały się $\mathrm{w}$ formie opublikowanej. I właśnie tym trzem utrwalonym w druku sztukom dramatycznym/scenariuszom scenicznym poświęcę baczniejszą uwagę w niniejszym artykule.

Życie seksualne dzikich Marcina Cecki i Krzysztofa Garbaczewskiego swym tytułem nawiązuje co prawda do słynnej pracy Bronisława Malinowskiego, ale nie tylko pomysł przepisania dzieła antropologa zainspirował twórców do przygotowania spektaklu, złożonego z „luźno splecionych sugestii, w których fantazja

11. Prokop-Janiec, Etnopoetyka..., s. 197.

12. Na temat kategorii punktu widzenia w badaniach literackich zob. np. Małgorzata Czermińska, Punkt widzenia jako kategoria antropologiczna i narracyjna w prozie niefikcjonalnej, w: Opowiadanie w perspektywie badań porównawczych, red. Zofia Mitosek, Kraków 2004. Zob. również: Prokop-Janiec, Etnopoetyka..., s. 208-213.

13. Greenblatt, Manifest badań nad mobilnością kulturową..., s. 47. 
rywalizuje z naukowością, żarliwość manifestu z beztroskim żartem, inspiracja filozoficzna i artystyczna - z wypowiedzią prywatną" ${ }^{\prime 4}$.

Ośrodkiem zainteresowania i głównym przedmiotem przedstawienia jest $\mathrm{w}$ tym utworze scenicznym postać badacza dzikich plemion i związany z tym problem kontaktu kulturowego, potraktowany zresztą w sposób niejednoznaczny i wielokontekstowy. Tak więc sztuka znakomicie wpisuje się w obszar refleksji nad transferem kulturowym, bo kwestią kluczową jest w niej sposób prezentacji „aktora” transferu, czyli antropologa doświadczającego spotkania z Innymi, a także - unaocznienie relacji międzykulturowej, powstającej wskutek obcowania badającego i badanych. Jest to relacja dość osobliwa z kilku względów. Przede wszystkim - ze względu na konsekwentne budowanie akcji z odniesień do przeszłości i przyszłości jednocześnie: świat fikcyjny przypomina bowiem w swym nastroju zarówno okoliczności wyprawy antropologa z początku XX wieku (np. scena spotkania Malinowskiego z Witkacym), jak i futurystyczną wizję wspólnoty ludzi, androidów i mutantów. Świadczy o tym już sam metatekstowy początek sztuki: w spisie osób przedstawionych znalazły się bowiem zarówno osobniki ludzkie i nie-ludzkie, jak i dość zagadkowa informacja o głównym bohaterze: „MALINOWSKI - Jack Malinowski, antropolog, tak jak Bronisław Malinowski tylko dziesiątki lat później”15. Także w prologu sztuki, czyli w wypowiedzi mutantki Arii, w jej słowach na temat Szarej Strefy, pobrzmiewają wątki nader współczesne, dotyczące społeczeństwa sieci, co pozwala traktować całą wypowiedź sceniczną jako wypełnioną aluzjami literackimi fantasmagorię o przodkach i następcach współczesnego cywilizowanego człowieka.

Świat sceniczny skonstruowany przez teatralny duet Marcin Cecko/Krzysztof Garbaczewski pełen jest dziwnych stworzeń i dzikiej, niemal ożywionej, budzącej przerażanie przyrody. Jest to świat obcy - nie dlatego jednak, że unaocznia utraconą bezpowrotnie przeszłość, ale $\mathrm{z}$ tego względu, że obowiązuje w nim zasada transformacji: mieszają się ze sobą zdarzenia pozornie realne i senne wizje bohaterów, przekształcają się postaci, zmienia się przestrzeń, a wprost proporcjonalnie do liczby tych zmian zwiększa się poczucie niepewności odbiorcy co do statusu świata przedstawionego i kondycji jego bohaterów. Można by stwierdzić, że ten świat fikcyjny budowany jest zgodnie z regułami groteski, ale to nie groteska wydaje się być nadrzędną kategorią decydującą o jakości estetycznej tego dzieła. Jest to bowiem rozpisany na sceny i dialogi, wielobarwny pod względem stylistycznym, teatralny esej o tożsamości człowieka, widzianej z perspektywy ideologii

14. Marcin Kościelniak, Nie-ludzkie, w: Marcin Kościelniak: „Młodzi niezdolni” i inne teksty o twórcach wspótczesnego teatru, Wydawnictwo Uniwersytetu Jagiellońskiego, Kraków 2014, s. 111.

15. Marcin Cecko, Życie seksualne dzikich, w: Transfer! Teksty dla teatru. Antologia, red. Joanna Krakowska, Wydawnictwo Krytyki Politycznej, Warszawa 2015, s. 234. 
posthumanistycznej. Bo taka właśnie perspektywa wydaje się najbliższa autorom, którzy włożyli w usta swych bohaterów, zwłaszcza tych określonych mianem Dzika/Dziki, szereg podręcznikowych haseł o końcu uprzywilejowanej pozycji gatunku ludzkiego. Znakomicie wypada na przykład scena przeprowadzania ankiety, w czasie której Malinowski chciałby uzyskać jakieś informacje na temat życia tubylców, a oni odpowiadają mu językiem wykładów naukowych:

\section{DEJAK DO}

Postęp ludzkich społeczeństw zmierza do transformacji ludzkiego gatunku. [...]

\section{ZETTO ZA}

Jeśli możemy myśleć o maszynach, to maszyny mogą myśleć. Jeśli jesteśmy w stanie pomyśleć maszyny, które myślą, to maszyny mogą myśleć o nas.

Epoka narodziła się w momencie wprowadzenia fizyki kwantowej i kubizmu. Konsekwencje obu są jasne, mówiąc słowami Heisenberga: „nie ma rzeczy, są tylko prawdopodobieństwa”. $[\ldots]$

\section{DEJAK DO}

Nie ma się czego bać. Świat zawsze był tak niepewny jak dziś. Jedyne co się zmieniło to, że dziś o wiele trudniej jest narzucić autorytet. Zwiększony przepływ informacji usuwa w cień autorytety, jest więcej informacji, a przez to jest mniej fałszywego poczucia pewności. Pewność, tak jak wiara, pojawia się w przypadku braku wszystkich informacji. $[\ldots]$

\section{ZETTO ZA}

Humaniści widzą siebie jako osobne istoty w antagonistycznej walce z otoczeniem. Posthumaniści postrzegają swoje istnienie jako wcielone w rozszerzony technologiczny świat ${ }^{16}$.

Przyznać trzeba, że takie poprowadzenie dialogu scenicznego frapuje radykalnością rozwiązań językowych. Postaci dramatyczne, będące (przynajmniej nominalnie) reprezentantami społeczności tradycyjnej, by nie rzec - prymitywnej, wyposażone zostały w język myśli ponowoczesnej. W moim przekonaniu nie jest to jednak pomysł artystyczny, który służyłby procesowi nobilitacji tubylców, czyli obrazowaniu upodmiotowionych dzikich. W tym zabiegu retorycznym chodzi raczej o podkreślenie konstrukcyjnego aspektu każdej pracy poznawczej człowieka, który nie tyle rozpoznaje, ile tworzy przedmiot oglądu, zgodnie $\mathrm{z}$ właściwymi mu procesami kognicji i wykształconą $\mathrm{w}$ ramach socjalizacji mapą pojęć. Bohaterem sztuki jest Jack, a nie Bronisław Malinowski, i choć działania tej postaci są artystycznym powtórzeniem antropologicznej przygody Bronisława Malinowskiego, to temat kontaktu $\mathrm{z}$ dzikimi istotami rozwija się zgodnie ze współczesnym pojmowaniem kulturowej odmienności - jako innego,

16. Cecko, Życie seksualne dzikich..., s. 260-261. 
ukrytego aspektu naszego „ja”. „U Garbaczewskiego „dzicy« - to my, umieszczeni w świecie spełniających się posthumanistycznych scenariuszy"17. Rzeczywistość przedstawiona w tym tekście teatralnym zaskakuje oryginalnością obrazu relacji Europejczyka z dalekim Innym.

Nie można odmówić sztuce daleko posuniętej erudycji - czy to w sposobie reprezentowania kwestii kontaktu kulturowego, czy też w zakresie językowego tworzywa tej reprezentacji. Dominuje w tekście styl naukowo-publicystyczny poważnej rangi, momentami kojarzący się z poetyką eseju. Sporo sformułowań zaczerpniętych zostało również z dziedziny technologii cyfrowej, dzięki czemu dialogi dramatyczne przypominają dywagacje o rozwoju cywilizacji w kierunku powstawania istot humanoidalnych. O naukowym podłożu problematyki sztuki świadczą również liczne odwołania do słynnych publikacji, między innymi do teorii Benoît Mandelbrota, Jerzego Szackiego czy właśnie Bronisława Malinowskiego. Odwołania te, niczym przypisy w stylu: „zobacz”, „porównaj”, umieszczone w nawiasach, w tkance dialogu dramatycznego, gwarantują efekt „układu rozkwitania” - tekst nabrzmiewa kontekstami i zaczyna przypominać organizację danych, których sposób wykorzystania i rozumienia zależy od użytkownika, niczym w hipertekście. Życie seksualne dzikich pomyślane zostało zatem jako wielowarstwowy dyskurs o charakterze palimpsestu: jego podstawą, i źródłem inspiracji, są dane z biografii antropologa Bronisława Malinowskiego, ale na bazie tych artystycznie przetworzonych informacji nawarstwia się wiele dodatkowych znaczeń, związanych z implantowaniem do tekstu prymarnych założeń posthumanizmu i krytyki postkolonialnej.

Orientacja ideowa scenariusza teatralnego i opartego na nim spektaklu znacząco wpływa na ukształtowanie wszystkich elementów składowych utworu: bohatera (bohaterów), miejsca i przebiegu zdarzeń. Antropolog Malinowski przedstawiony został nie tylko jako badacz tubylczej ludności, lecz także jako badany obiekt, o czym świadczy na przykład znakomita scena pod tytułem Bram$k a$, przypominająca sytuację odprawy celnej, podczas której bohater zmuszony jest do okazania wszystkiego, co posiada, a także do przejścia przez kontrolne bramki. Pikanterii dodaje tej scenie fakt, że kontroli dokonuje para osobników o ciekawie brzmiących imionach: Dejak Do - Dzika i Peto Pa - Dziki. Wspomniani bohaterowie, podobnie jak inni dzicy występujący w sztuce, nie tylko nie są zwykłymi przedstawicielami społeczności tubylczej, ale ponadto mają zdolność dogłębnej samooceny, z pełną świadomością konstrukcyjnego aspektu tożsamości człowieka. Jakże ironicznie, a nawet cynicznie, brzmią fragmenty sztuki, kiedy Malinowski usiłuje pozyskać przychylność, przekupić i zbadać jednego z rodowitych mieszkańców wyspy o imieniu Estoseb. Podczas tego spotkania okazuje

17. Kościelniak, Nie-ludzkie..., s. 111. 
się bowiem, że Dziki świetnie mówi po angielsku, potrafi swobodnie zmieniać kierunek rozmowy, a przede wszystkim znakomicie wykorzystuje różne konwencje wypowiedzi - na przykład po otrzymaniu od antropologa daru w postaci złotej figurki, dziękuje słowami kopiującymi formę przemowy oscarowej. Sytuacje dramatyczne zaskakują zatem sposobem poprowadzenia interakcji bohaterów, które z przewidywalnego układu sił w starciu biały człowiek - dziki człowiek zmieniają się w niekonwencjonalny obraz wzajemnej ciekawości i podejrzliwości w procesie rozpoznawania się osobników, przedstawionych jako istoty żywe, równoprawne w swych zachowaniach i przekonaniach.

Na podobnej zasadzie - frapujących zagadkowością rozwiązań kompozycyjnych - zbudowana została przestrzeń akcji. Już na samym początku sztuki, w Prologu, mutantka Aria snuje opowieść o Szarej Strefie, którą - nieco wbrew etymologii słów - bohaterka traktuje jako utraconą przestrzeń wolności i szczęścia. Dowiadujemy się z tego monologu, że wielokrotnie opuszczała ona Szarą Strefę, czyli siedzibę Dzikich, czując przy tym spory dyskomfort psychiczny i „silny niepokój”. Miejsce to kojarzy się bowiem Arii z czułością, poczuciem wspólnoty, szczerością i autentycznością relacji w ramach bytowania grupy w jednym miejscu, w przestrzeni wymiany impulsów. W dalszych fragmentach sztuki teren akcji zaprezentowany został jednak już znacznie inaczej. Przede wszystkim jako sfera liminalna, „trudne przejście między światami” (s. 251), które zmuszony jest pokonać antropolog Malinowski. Nowa, eksplorowana przez niego przestrzeń, widziana oczami badacza, to pejzaż męczący i przerażający:

W tym miejscu, w którym brak powietrza, w którym człowiek wciąż duszy się i męczy, w którym ślamazarnieje i omdlewa psychicznie, wegetacja panująca bezwzględnie i wszechwładnie z całym okrucieństwem odmawia mu nawet platonicznego przygarnięcia, otuchy i pokrzepienia. Odpycha go zupełnie i bezlitośnie, z naciskiem zaznacza swe jedynowładztwo. Nawet rozległe widoki są dość obce ${ }^{18}$.

Miejsce zdarzeń, niejednorodne jeśli chodzi o jakość tworzących je składników i niejednoznaczne pod względem aksjologicznym, wymyka się zatem każdej próbie racjonalnego oglądu - i ze strony bohatera, i ze strony obserwatora zewnętrznego (czytelnika, widza przedstawienia). Wydaje się, że autorzy sztuki za cel swój obrali mnożenie przeciwieństw i kontrapunktowanie przebiegu akcji zestawieniami zdarzeń z różnych porządków opisu świata. Dyskurs antropologiczny spod znaku postkolonialnej narracji o Inności splata się ze sprawdzonymi technikami literatury grozy, a także z literacką futurologią. Świat pełen różnych dziwacznych istot, przepełniony energią nieożywionej materii, sprawia wrażenie przestrzeni

18. Cecko, Życie seksualne dzikich..., s. 251. 
nieprzyjaznej dla istoty ludzkiej, w której nie ma racji bytu jakakolwiek cywilizacyjna ogłada. Sposób kreacji tej niejednorodnej i zmiennej w swych kształtach przestrzeni kojarzy się po pierwsze z postawą nieufności wobec intelektualnych aspiracji czy technologicznych osiągnięć współczesnego człowieka, po drugie - z posthumianistyczną ideą postrzegania współczesnej kondycji ludzkiej jako jednego $\mathrm{z}$ etapów w ewolucji świata, bynajmniej nie najważniejszego. $Z$ perspektywy późniejszej praktyki twórczej duetu Marcin Cecko/Krzysztof Garbaczewski, przestrzeń zbudowana w Życiu seksualnym dzikich znajduje swój odpowiednik w kompozycji wyspy Prospera, czyli w inscenizacji Szekspirowskiej Burzy z 2015 roku. I w jednym, i w drugim przedstawieniu pojawia się bowiem motyw tajemniczego odludzia, jakiejś przestrzeni działania potężnych sił przyrody, przestrzeni wypełnionej obecnością istot nie-ludzkich.

Nie można zapomnieć, że na bazie wszystkich wspomnianych powyżej pomysłów artystycznych duetu Cecko/Garbaczewski wyeksponowany został ważny motyw kontaktu kulturowego. Powraca on w wielu odsłonach i wariantach, nie tylko w swej zasadniczej wersji obrazowania relacji Europejczyka z dalekim Innym $^{19}$. W scenach dramatycznych pojawiają się bowiem nawiązania do różnych pól znaczeniowych słowa 'kontakt'. Używane jest ono w celu zaznaczenia potrzeby bliskości człowieka $\mathrm{z}$ drugim człowiekiem, w nawiązaniu do specyfiki komunikacji medialnej w społeczeństwie sieci, a także - dla wyeksponowania lęku jednostki przed Obcym, pojmowanym zarówno istotowo (jako ktoś konkretny, kogo można poznać, a także wykreować swym spojrzeniem), jak i bezosobowo (jako zagrażająca człowiekowi materia świata, która w każdej chwili przeobrazić się może w siłę niszczącą). O takim wieloaspektowym traktowaniu tematu kontaktu kulturowego świadczy już sam pomysł doboru postaci przedstawionych. Wieloosobową społeczność sztuki tworzą: dwóch ekscentryków, czyli Malinowski i Witkacy, kilku dzikich osobników oraz outsider, android i mutantka.

Życie seksualne dzikich to sztuka o konstruowaniu tożsamości: w relacji z Innymi, z pasją poznawczą, ale i ze świadomością kulturowego naznaczenia jednostki dokonującej myślowego oglądu siebie i świata. Jesteśmy mocno restrykcyjni i równie mocno naiwni w procesie recepcji obcych treści kulturowych - zdają się mówić swym przedstawieniem Marcin Cecko i Krzysztof Garbaczewski. Wyposażeni w bagaż mądrych naukowych narracji, podejmujemy próbę opisu i oceny Innych, nie zdając sobie sprawy nie tylko z cząstkowości własnego spojrzenia, ale również nie biorąc pod uwagę możliwości porażki w próbach zbudowania głębokich,

19. Pojęcie kontaktu kulturowego w odniesieniu do dzieł Bronisława Malinowskiego i interpretujących je badaczy jest przedmiotem dokładnej analizy w artykule: Adam Pisarek, Antropolog, czyli gość. O badaniach terenowych Bronisława Malinowskiego jako formie kontaktu kulturowego, „Laboratorium Kultury”, 2013, nr 2, s. 60-90. 
pozbawionych uprzedzeń relacji osobowych. Znakomicie świadczy o tym scena wymiany tożsamości, kiedy to Malinowski usiłuje zbliżyć się do swych nowych pobratymców, ale udaje mu się tylko powtarzać za nimi fragmenty wyliczanych słów, z naciskiem na sylabę „-ja”. Fiasko poniesione w kontakcie z tubylcami oraz motyw utraty pamięci o przodkach, pojawiający się w słowach Arii (a budzący skojarzenie z wierszem Jaszczur Wisławy Szymborskiej) - wszystko to pozwala wnioskować, że jednym $z$ ważnych problemów sugerowanych w sztuce jest wizja wspólnoty ludzi jako skupionych na sobie monad, tęskniących za autentycznym, bliskim kontaktem $\mathrm{z}$ drugą istotą, a zarazem pozbawionych poczucia bezpieczeństwa w świecie groźnej przyrody i rozwijającej się w szybkim tempie technologii. Powracający motyw kontaktu kulturowego można traktować zatem jako przewrotną metaforę, demaskującą iluzoryczne przekonanie o możliwości rozpoznania Innego i stworzenia z nim takiej płaszczyzny porozumienia, która gwarantuje wzajemne poczucie bezpieczeństwa.

Performatywny finał sztuki (zapis sceniczny wskazuje tylko, że w tym momencie przedstawienia następuje improwizacja aktorska) niweluje poniekąd tę sceptyczną wizję destrukcji jednostkowych tożsamości i rozpadu ludzkiej wspólnoty. Teatralny popis aktorski w wykonaniu Jacka Poniedziałka, Macieja Stuhra i Krzysztofa Zarzeckiego niesie nadzieję dzięki nobilitacji rzeczy błahych, przyziemnych i dzięki grze teatralnej - demonstracji udawania ku uciesze publiczności ${ }^{20}$. Czyżby ten namacalny przykład radości życia, płynącej z materialnych drobiazgów i obecności swobodnych ciał aktorskich na scenie, miał szansę stać się antidotum na egzystencjalny lęk wyrażony w spektaklu groteskową, futurologiczną wizją zaniku autonomicznych podmiotowości w obcym świecie wielu humanoidalnych stworzeń?...

Magda Fertacz w swej sztuce Śmierć Kalibana z 2012 roku inaczej podejmuje problematykę konfrontacji kultur. Oś dramaturgiczna utworu Fertacz skomponowana została $\mathrm{z}$ dwóch równoległych zagadnień: po pierwsze - tematem nadrzędnym jest problem uchodźców, zaludniających Europę w poszukiwaniu lepszego i bezpieczniejszego życia, po drugie - autorka poruszyła kwestię skrajnych eksperymentów artystycznych, przekraczających granice zdrowego rozsądku i etycznego wymiaru człowieczeństwa. Sposób pokazania relacji ludzi spoza Europy („,czyli z Tam”) i białych Europejczyków („czyli z Tu”) jest przerażający,

20. Życie seksualne dzikich [Spektakl inspirowany dziełami Bronisława Malinowskiego Życie seksualne dzikich w pólnocno-zachodniej Melanezji, Dziennik w ścistym znaczeniu tego wyrazu oraz Argonauci zachodniego Pacyfiku], reż. K. Garbaczewski, scenariusz i dramaturgia: M. Cecko, Nowy Teatr Warszawa, premiera: 14.04.2011. 
ponieważ nosi znamiona nowego kolonializmu. Akcja rozwija się wokół projektu bohaterów, reprezentujących Organizację Zarządzania Dobrem, którzy wpadli na pomysł prywatyzowania uchodźców, ponieważ jest to:

[...] jedyne lekarstwo na gruźlicę wykluczonych, na tyfus niemocy i braku działania, na odrę niespełnionych obietnic, na grypę biedy i katastrofalnego głodu, czarną ospę nieudolnej polityki imigracyjnej ${ }^{21}$.

Prywatyzacja polega na całkowitym podporządkowaniu i ubezwłasnowolnieniu obcych, na wykorzystywaniu ich do różnych niewdzięcznych prac fizycznych, w zamian za zabezpieczenie podstawowych potrzeb życiowych. Imigranci osiedlani są w małych ,self-hausach” (s. 23), czyli boksach usytuowanych w obozach dla uchodźców. Tutejsi biali ludzie z aspiracjami mają prawo do podglądu i wyboru poszczególnych ciemnoskórych osobników, według własnych potrzeb. Jeden z Haitańczyków trafia na przykład do galerii Artysty, żeby stać się tworzywem eksperymentu w pełnym tego słowa znaczeniu, bo z czarnym bohaterem osadzonym w sterylnie białej przestrzeni galerii można zrobić dosłownie wszystko. W przebieg niecodziennego performansu włączony jest również Zwykły Człowiek, który decyduje się poświęcić wiele, żeby ocalić życie imigranta, nawet pomimo faktu, że to właśnie ten ostatni ma zostać w zamyśle autora eksperymentu dawcą serca dla Zwykłego Człowieka. Sztuka kończy się śmiercią „,zzarnego kadłubka”, czyli imigranta pozbawionego wielu swych organów z woli osób uczestniczących w artystycznym projekcie. Utwór kończy się występem postaci o nazwie Ostatni Głos, która śpiewa piosenkę z filmu Asgera Letha Ghosts of Cite Soleil.

Wbrew powyższemu krótkiemu opisowi treści dramatu, sztuka Magdy Fertacz nie ma w sobie nic z epatowania okrucieństwem i przemocą. Jest tekstem nacechowanym emocjonalnie, momentami sarkastycznym w swej wymowie, na pewno zrodzonym z gniewu, ale i poczucia bezradności autorki wobec procedur dyskryminowania Innych w naszym europejskim, cywilizowanym świecie. Magda Fertacz to pisarka w pełni świadoma niewielkiej roli, jaką może odegrać sztuka w zakresie łagodzenia konfliktów kulturowych czy znoszenia poczucia dystansu i niechęci wobec dalekich Innych. „Obrazuję problem, ale i tak pozostaję od niego odseparowana” - stwierdza autorka w komentarzu do swej sztuki, którą nazywa „koncertem-protestem”22. Nie zmniejsza to jednak efektu oddziaływania tekstu teatralnego, bo Śmierć Kalibana porusza odbiorcę i budzi jego dyskomfort poznawczy. Ostentacyjnie wskazuje bowiem binarność w układzie relacji między-

21. Magda Fertacz, Śmierć Kalibana, „Dialog”, 2012, nr 3, s. 31.

22. Jeśli denerwuję, to dobrze. Rozmowa z Magdą Fertacz [Rozmawiała Justyna Jaworska], „Dialog”, 2012, nr 3, s. 43, 42. 
ludzkich opartych na różnicy między lepszymi i gorszymi gatunkowo istotami oraz ostrzega przed nowym wariantem kolonizowania tych, którzy $\mathrm{z}$ różnych względów zajmują niższe miejsce w hierarchii społecznej. O restrykcyjnych i przemocowych aspektach w funkcjonowaniu wielokulturowej zbiorowości pisze Magda Fertacz językiem ekonomii i publicystyki politycznej, tworzy jednak $\mathrm{z}$ tych zasobów różnych dyskursów sformułowania atrakcyjne pod względem retorycznym, momentami wręcz poetyckie. Partie publicystyczne w wypowiedziach postaci dominujących (KOBIETA, MĘŻCZYZNA, DOBRY) skontrastowane są z lirycznymi wyznaniami osób pogardzanych i wykluczonych (CZARNY, KTÓRY POŁKNĄŁ SYNA, SPRZĄTAJĄCA, DŻEMAL) oraz z partiami CHÓRZYSTKI, stanowiącej „plastikową i zarazem egzaltowaną ikonę współczesnego świata dobrobytu"23. Monolog CZARNEGO, KTÓRY POŁKNĄŁ SYNA, podobnie jak samba SPRZĄTAJĄCEJ, napisana mową wiązaną, to nasycone negatywnymi emocjami ekspresywne wyznania obrazujące bezradność/naiwność istot skazanych przez swą etniczną odrębność na wegetację w najniższym punkcie drabiny społecznej:

SPRZĄTAJĄCA

Jestem jak te śmiecie

Papier plastik szkło

Nikt nie wie że jestem

Ale to się zmieni

To się już zmieniło

Jestem wasza

Dla was ta samba

Dla was moje biodra

Tańczę i śpiewam swoją sambę

Za brudną pracę

Dostanę czyste pieniądze dzieci nie pytają

Dzieci jedzą

Łatwo jest na ulicy

Się sprzedawać

Łatwo zabierać torebki bogatym

Je tego nie robię

Moja praca jest uczciwa

Jak moja samba

Dla was ją tańczę

I śpiewam depcząc miękką ziemię

Jardi Gramacho

Największej góry śmieci w Rio

Biedne są śmiecie biedoty

Bogate są śmiecie bogatych

23. Jeśli denerwuję, to dobrze. Rozmowa z Magda Fertacz..., s. 42-43. 
Biedni pakują w małe worki

I ja pakuję w małe worki

Jestem materiałem do odzysku

PET PP PCV

Papier metal szkło

Każdy z was też może

Nie wiesz kiedy to się stanie

Będziesz materiałem do odzysku [... $]^{24}$.

Magda Fertacz poruszyła również w swym utworze niezwykle istotną sprawę kontrowersyjnych przekroczeń w praktykach artystów-performerów. We współczesnym świecie niezliczonych performansów artystycznych nietrudno znaleźć bowiem przykłady działań, które - transgresyjne w założeniu - opierają się na różnych aktach prowokacji względem reguł życia społecznego w celu stawiania pytań o granice norm etycznych i godność człowieka. Dramatopisarka, zainspirowana projektami Hiszpana Santiago Sierry, stworzyła w swej sztuce radykalną postać Artysty, który - podobnie jak Sierra - „używa przemocy jako środka wyrazu artystycznego"25. Bohater sztuki Magdy Fertacz powoduje swym projektem artystycznym zarówno śmierć człowieka, jak i moralne upodlenie współuczestników tego okrutnego eksperymentu. Znęca się psychicznie nad Zwykłym Człowiekiem, oczekującym na transplantację serca, i wyzwala sadystyczne instynkty w obserwatorach akcji, którzy sterują przebiegiem zdarzeń online, czyli wymyślają, co można zrobić z ciałem uwięzionego w galerii ciemnoskórego człowieka.

Problem, jaki sygnalizuje autorka Śmierci Kalibana, nie leży tylko w kwestii kontrowersyjnych działań artystycznych, wykorzystujących ludzi jako materiał sztuki i zyskujących szeroki oddźwięk medialny w naszym stechnicyzowanym świecie. Równie istotny jest bowiem fakt społecznego rezonansu podobnych, restrykcyjnych i przemocowych praktyk wykorzystywania ludzi, którzy z różnych względów (zdrowotnych, społecznych czy etnicznych) są słabsi, podporządkowani, wykluczeni. Autorka mówi z niepokojem: „idąc do galerii, płacimy za komfort bezpiecznego oglądania tego, co otacza nas w realnym życiu, ale udajemy, że tego nie ma" i następująco, niezwykle dobitnie, określa postawę współczesnych odbiorców różnych eksperymentalnych praktyk artystycznych: „To bardzo wygodna, sterylna forma obojętności" ${ }^{26}$. Tym samym Magda Fertacz nie tylko wpisuje swój dramat w nurt wypowiedzi literackich dotyczących konfrontacji kultur, w tym sposobu traktowania imigrantów i recepcji właściwych im zachowań kulturowych, lecz także skłania czytelników swym niepokornym tekstem do namysłu nad pro-

24. Fertacz, Śmierć Kalibana..., s. 36-37.

25. Jeśli denerwuję, to dobrze. Rozmowa z Magda Fertacz..., s. 43.

26. Jeśli denerwuję, to dobrze. Rozmowa z Magdą Fertacz..., s. 43. 
cesami myślenia o dalekich Innych, do refleksji o podejmowanych wobec nich działań dyscyplinujących - w myśl podejrzanie brzmiącego poczucia wyższości, czy to obyczajowej, czy etycznej, czy ekonomicznej.

Szekspirowski Kaliban, przywołany w tytule sztuki Magdy Fertacz, jest zatem figurą wykluczonego Innego. Autorka z pewnego rodzaju zażenowaniem przypomina o aktualności kolonialnego stylu myślenia, w ramach którego każdy obcy, niczym Kaliban, ucieleśnia

[...] sprzeczną z ideałem oświeconego człowieka prymitywną i nieokiełznaną racjonalnym myśleniem nieobyczajność, płynącą z dominacji zwierzęcego pierwiastka nad właściwą ponoć tylko ludziom duchowością ${ }^{27}$.

Świat przedstawiony w dramacie jest właśnie taką wizją nowego oblicza kolonializmu, ukrytego pod pozorem szlachetnej idei wspierania imigrantów i zapewniania im odpowiednich warunków bytowych. A postać Artysty, którą wykreowała dramatopisarka, pozostaje współczesnym odpowiednikiem Prospera, jeśli oczywiście ująć tę postać zgodnie z interpretacją postkolonialną - jako człowieka „władzy i wiedzy”, wykorzystującego w swych aktach twórczych każdego podrzędnie traktowanego obcego/Innego.

Przesłanie sztuki nie ogranicza się do sygnalizowania problemów związanych ze zjawiskami dyskryminacji i uchodźctwa, ani tym bardziej nie wiąże się z intencją budzenia naiwnego współczucia wobec losu przybyszy. Ostre stylistyczne środki wyrazu, jakie zastosowała autorka w swym „poszarpanym” tekście, służą przede wszystkim wskazaniu kompletnej bezradności tak zwanego „dobrego człowieka”, czyli potencjalnie każdego z nas - człowieka cieszącego się względnym dobrobytem i wolnością, a jednak uwikłanego w system państwowego zarządzania zasobami ludzkimi. Autorka sztuki, podobnie jak wielu innych twórców podejmujących problem konfliktów i napięć etnicznych we współczesnym wielokulturowym świecie, przestrzega przed powierzchownymi wzruszeniami sytuacją ludzi wykluczonych. Dramat skłania do przemyśleń, niewygodnych z perspektywy dobrego samopoczucia Europejczyka:

Wydaje się, że jedyną właściwą reakcją może tu być wstyd, a właściwie uświadomienie sobie własnego uwikłania i doświadczenie winy. Współczucie na widok cierpienia innych to reakcja aż nazbyt łatwa i przez to nieodpowiednia, to reakcja konwencjonalna i dobrze przyswojona, szczególnie dlatego, jak się zdaje że pozwala każdorazowo przeoczyć strukturalną przemoc i wyzysk, które leżą u podstaw cierpienia ${ }^{28}$.

27. Małgorzata Sugiera, Inny Szekspir, Wydawnictwo Księgarnia Akademicka, Kraków 2009, s. 59.

28. Katarzyna Bojarska, (Nagie) życie Kalibana i pytania o sztukę, „Dialog”, 2012, nr 3, s. 49. 
Smutki tropików Mateusza Pakuły to sztuka zdecydowanie odmienna od dwóch opisanych powyżej tekstów teatralnych. Pakuła proponuje inny, zgodny ze swym dramaturgicznym stylem, radykalny wariant obrazowania relacji Europejczyków z przedstawicielami egzotycznych kultur. Nie chodzi tu o doświadczenia antropologa-badacza, ani tym bardziej o migrację i problemy uchodźców, ale o zjawisko masowej turystyki do różnych odległych zakątków świata. Autor sztuki nawiązuje do znanych motywów literackich: w sześciu częściach tekstu, opatrzonych dosadnymi tytułami-hasłami, zaprezentowani zostali bohaterowie, którzy wyruszają w świat z ciekawości, z tęsknoty za wyspami szczęśliwymi, z zamiarem ucieczki od swego dotychczasowego życia, a także z powodu żądzy przygód czy potrzeby sensacji. Utwór sceniczny bezlitośnie demaskuje zarówno złudne przekonania i nadzieje turystów co do wartości celu ich podróży, jak i bardzo przeciętną, momentami karykaturalną bądź podejrzaną kondycję samych podróżników. Postaci sztuki, lakonicznie określone zaledwie jedną literą alfabetu (B1, B2, B3, B4, B5, B6), są uproszczonymi figurami dramatycznymi, o ograniczonym potencjale intelektualnym, za to $\mathrm{z}$ nadmiernie rozbudowanym ego. To postaci „mówione językiem”, czyli kolokwialną, nieskładną frazą, pełną powtórzeń, błędów i typowych dla idiolektu autora zaskakujących neologizmów. Język sygnalizuje powierzchowność myśli bohaterów, stereotypowość ich sądów i dążenie do ekstremalnych doznań. B1 i B3 prowadzą na przykład rozmowę o różnych regionach turystycznych dalekiego świata, akcentując przy tym poczucie wyższości Europejczyka i przedmiotowe podejście do innych kultur:

\section{B1}

[...] No jakoś tak niedawno wróciłam z takiej można powiedzieć nawet że podróży życia i powiem ci że te Indie mnie jakoś nie zachwyciły szczerze mówiąc. Trochę powiem ci w mojej opinii przereklamowane według mnie. No wiesz jakby o co chodzi. Filipiny niby ładne no ładne nie powiem no wiesz no powiem ci że ładne ale nie ma tam za bardzo co robić. Nic specjalnego po prostu. Może na tydzień ale dłużej nie za bardzo. Ale Indii to ci nie polecam wiesz. Trochę tam jednak przesadzają z tą ilością brzydoty ulicznej na ulicy wiesz tej szpetoty ze smrodu ilością bo wszędzie jakieś straszne smrody wręcz fetory czyhają na twoje delikatne jednak bądź co bądź cywilizowane wychowane w kulturze śródziemnomorskiej wiesz powonienie. No powiem ci za dużo tam tych takich wiesz połamańców żebrzących takich że tak powiem obesranych no nie jest to estetyczne nawet jak ktoś lubi takie rzeczy ${ }^{29}$.

29. <http://www.gnd.art.pl/wp-content/uploads/2014/05/smutki_tropikow_mateusz_pakula. pdf>, s. 3 (29.09.2017). 
B4 z kolei to neurotyczny osobnik, który ucieka na Alaskę, by żyć wśród niedźwiedzi jako Grizzly-man, B5 czuje się w podróży jak Bruce Willis i wyobraża sobie siebie $\mathrm{w}$ roli korespondenta wojennego, dostarczającego newsy do gazet (oczywiście wiadomości o najbardziej drastycznych i krwawych zdarzeniach wojennych). B2 przygotowuje się do wyjazdu na wymarzone Wyspy Owcze, które według opinii B3 były w latach siedemdziesiątych XX wieku miejscem masowych gwałtów na dziewczynkach. Wszystkie te oznajmienia, zawarte w dialogach bohaterów, wydają się bełkotem informacyjnym, zarówno ze względu na status wygłaszających je postaci (dość osobliwych, bo pospolitych i jednocześnie skłonnych do zachowań co najmniej ekscentrycznych), jak i z powodu cech charakterystycznych całego świata fikcyjnego - oscylującego na granicy zdarzeń realnych i wyobrażonych, retrospekcji i konfabulacji, groteski i podrzędnej publicystyki.

Odległe kraje, na przykład Indie, Wietnam czy Filipiny, stają się dla bohaterów tej sztuki miejscem upragnionych zdobyczy materialnych i niezwykłych doświadczeń. Nie chodzi jednak o typowe dla turysty przeżycia poznawcze i emocje płynące z kontaktu z innymi kulturami. Zdecydowanie bardziej pożądane są wrażenia ekstremalne, powstające wskutek podglądania scen przemocy czy też gromadzenia pamiątek związanych z działaniami wojennymi i ludzkim cierpieniem (np. zapalniczki z Sajgonu czy „filmy z tortur Saddama”).

Przemierzając te przestrzenie zarażone śmiercią, bohaterowie dramatu, pod pozorem uczestnictwa, konsumują turystyczne atrakcje jedynie dla sportu, z bezpiecznej odległości przyglądając się piekłu na Ziemi. Kolejne podróże, zarówno te rzeczywiste, jak i wirtualne, znieczulają ich na zło i wyostrzają apetyt na coraz bardziej ultraradykalne doznania ${ }^{30}$.

Sztuka Mateusza Pakuły, skrajnie ironiczna w zakresie środków reprezentacji, stanowi świadectwo nieudanego, bo restrykcyjnego i naznaczonego dominacją „białych”, transferu kulturowego. Z jednej strony postaci przedstawione charakteryzuje pełna gotowość do przyjmowania odmiennych treści kulturowych i potrzeba konfrontacji z tym, co egzotyczne, z drugiej zaś strony - ich zdolność do percepcji odmienności ogranicza się do myślenia stereotypami, przy całkowitym braku empatii i postawy otwarcia wobec innych. W swych sądach i przekonaniach ci „nowocześni” turyści kierują się poglądami zasłyszanymi na przykład w publicystyce medialnej i wyobrażeniami powstającymi na podstawie reklam:

B2

Szukałam raju. Kocham wyspy. Tak się złożyło że kocham wyspy. Kochanie wysp weszło mi w krew gdy oglądałam „Rambo: Pierwsza krew” i były reklamy. I to było Reno Clio

30. <http://www.gnd.art.pl/laureaci/> (28.09.2017). 
reklama a potem Bounty batonik. I tam był ten raj bo była palma ze srebrzystym kokosem który się sam z uśmiechem rozłupywał i błękitna laguna z rafą i opalone piękne ciała bez pryszczów. I to był raj że hej $j^{31}$.

Wypowiedzi bohaterów, nasycone egocentryzmem i podziwem dla celebrytów, sugerujące szczątkową wiedzę o dalekich krajach, stanowią osobliwą mieszankę fascynacji rdzennymi kulturami i pogardy wobec Inności. Sceny sztuki tworzą zatem karykaturalny obraz kontaktu kulturowego, w czasie którego nie ma miejsca (i potrzeby) na powstanie jakiejkolwiek wartościowej i długotrwałej relacji międzyludzkiej. A przede wszystkim - unaoczniają kulturę europejską w stanie kryzysu. Znaczącym przejawem tego stanu jest zjawisko „turystycznej ekscytacji, która w gruncie rzeczy zawsze ma kolonialny podtekst"32.

Mateusz Pakuła przewrotnie nawiązuje do Smutku tropików Claude’a Lévi-Straussa. Podważa wartość europejskiego modelu kultury, szydzi z utopijnego postrzegania życia dalekich Innych, rezygnuje z melancholijnego dystansu wobec przedmiotu reprezentacji na rzecz językowej gry stereotypami i stylami wypowiedzi. „Pyta o przyczynę gorączki podróżowania trawiącą młode pokolenie, zwracając uwagę na zapośredniczony charakter naszych doświadczeń nieuchronnie wplątanych w sieć bieżących uwarunkowań społecznych, historycznych i kulturowych"33. Sarkastyczne spojrzenie autora sztuki na współczesnego „człowieka europejskiego”, który - sam pełen fobii oraz kompleksów - w sposób instrumentalny i merkantylny traktuje przedstawicieli innych kultur, stało się jednym z powodów przyznania autorowi Smutków tropików Gdyńskiej Nagrody Dramaturgicznej w 2014 roku. W uzasadnieniu werdyktu konkursu czytamy bowiem:

Za największą wartość utworu Mateusza Pakuły Kapituła uznała przedstawienie rzeczywistości, w której obrazy cudzego cierpienia i odległych światów stają się dla bohaterów iluzją realnych doświadczeń, a żywy i pełen inwencji język dramatu odsłania niemożność autentycznej komunikacji ${ }^{34}$.

Lektura powyższych tekstów teatralnych prowadzi do wniosku, że zjawisko konfrontacji kultur jest istotnym tematem podejmowanym we współczesnej

31. <http://www.gnd.art.pl/wp-content/uploads/2014/05/smutki_tropikow_mateusz_pakula. pdf>, s. 21 (29.09.2017).

32. Witold Mrozek, Horrory boskiej popkultury <http://www.e-teatr.pl/pl/artykuly/174612. html?josso_assertion_id=557038BE8EA354BF> (26.06.2019).

33. Agata Dąbek, Podróż do miejsc niemożliwych <http://teatralny.pl/recenzje/podroz-do-miejsc-niemozliwych,198.html> (02.12.2017).

34. <http://www.gnd.art.pl/aktualnosci/> (28.09.2017). 
polskiej twórczości scenicznej. Można dodać jeszcze, że w odniesieniu do opisanych utworów dramatycznych teoria transferu kulturowego znajduje adekwatne zastosowanie. Omawiana twórczość teatralna nie jest wyłącznie reprezentacją „pojedynczych zjawisk kulturowego kontaktu” ${ }^{35}$. Jest natomiast świadectwem

długotrwałych procesów rozwojowych wzajemnych kulturowych interferencji oraz tych wpływów, które dziś po części zanikły i dają się odnaleźć tylko w pamięci kulturowej pewnych grup, ich skutki jednak wciąż są zauważalne ${ }^{36}$.

Autorzy sceniczni eksponują w swych utworach znaczną przemianę krajobrazu kulturowego; bazą ich pomysłów dramaturgiczno-fabularnych jest bowiem ta sfera życia publicznego, w której coraz częściej podejmowane są dyskusje o procesach integracji, asymilacji czy też marginalizacji kultur obcych ${ }^{37}$. Jednym $\mathrm{z}$ ważniejszych zagadnień poruszanych przez autorów piszących dziś dla sceny jest „zarówno dostosowanie nowych treści do własnej kultury, jak i zmiana własnej kultury pod ich wpływem" ${ }^{38}$. Współczesna twórczość teatralna wpisuje się tym samym w rozległy obszar działań artystycznych i edukacyjnych, inicjujących „twórcze zainteresowanie wielokulturowością" ${ }^{39}$ - na zasadzie pozytywnego transferu, wbrew praktykom dyskryminacyjnym oraz binarnym podziałom na kultury dominujące i podporządkowane.

Omówione w artykule sztuki sceniczne nie są jedynie papierowymi tekstami. Każda z nich miała swój pokaz premierowy, czy to w postaci przedstawienia teatralnego, czy też $\mathrm{w}$ formie publicznego czytania ${ }^{40}$. Komentarze i dyskusje wzbudzone przez te utwory potwierdzają fakt, że etniczna odmienność ciągle pobudza wyobraźnię artystów, skłaniając ich do ukazywania w swych dziełach różnych, niekoniecznie pozytywnych, przykładów konfrontacji ludzi pochodzących z odległych sobie kultur. W odniesieniu do omawianych tekstów teatralnych

35. Joanna Jabłkowska, Transfer kulturowy czy po prostu kontakty?, w: Teatr - literatura - media. O polsko-niemieckich oddziaływaniach w sferze kultury po 1989 roku, red. M. Leyko, A. Pełka, Łódź 2013, s. 34.

36. Jabłkowska, Transfer kulturowy czy po prostu kontakty?..., s. 34 .

37. Zob. Karolina Prykowska-Michalak, Transfer kultury - przypadek teatru polskiego i niemieckiego, w: Monolog - dialog - transfer..., s. 190-191.

38. Prykowska-Michalak, Transfer kultury..., s. 190.

39. Jabłkowska, Transfer kulturowy czy po prostu kontakty?..., s. 37.

40. Bronisław Malinowski, Życie seksualne dzikich, reż. Krzysztof Garbaczewski, scenariusz i dramaturgia: Marcin Cecko, Teatr Nowy Warszawa, premiera: 14.04.2011; Szekspirowskie czytanie: Śmierć Kalibana Magdy Fertacz, Teatr w Oknie Gdańsk, reż. Adam Nalepa, 05.08.2013; Mateusz Pakuła, Smutki tropików, reż. Paweł Świątek, Teatr Łaźnia Nowa Kraków, premiera: 08.12.2013; Magda Fertacz, Śmierć Kalibana, reż. Przemysław Jaszczak, Teatr Gløsoli Wrocław, premiera: 27.07.2014. 
zauważyć również trzeba, że artystyczna reprezentacja Inności służy pogłębionej refleksji tożsamościowej. Jest z pewnością wynikiem specyficznej koniunktury, którą należy rozumieć jako „krytyczne podejście do deficytów istniejących we własnej kulturze" ${ }^{\prime 41}$. Daje również podstawę do namysłu nad dynamiką procesu przyswajania/przekształcania tego, co obce. Jak pokazują autorzy piszący dziś dla sceny, w wielu przypadkach wspomniany proces opiera się albo na regule zawłaszczania i redukcji Inności, albo na „ujednolicaniu się" kultur w homogenicznej masie ludzkiej zglobalizowanego świata.

Niewątpliwą wartością tekstów pisanych współcześnie dla teatru jest potencjał angażowania odbiorcy. Autorzy nie przebierają w środkach i stawiają śmiałe tezy, aby zniwelować nasze poczucie neutralności wobec problemów przedstawionych. Ich sztuki prowokują do zajęcia krytycznej postawy, zarówno wobec zastosowanych środków reprezentacji, które z założenia mają budzić etyczno-estetyczny opór, jak i wobec sygnalizowanych w tekstach antagonizmów kulturowych i złudzeń poznawczych Europejczyka na temat „dzikich” i „tropików”. Ponadto, dialogując z gotowymi tekstami antropologicznymi czy literackimi, Marcin Cecko, Magda Fertacz i Mateusz Pakuła zabierają głos w kwestii ambiwalentnej pamięci kulturowej, konstytuowanej „przez przeciwstawne odczucia zachwytu i resentymentu, pragnienia i odrzucenia”42. Ich „rebelianckie” teksty zachęcają do myślenia o dalekim Innym poza układem relacji dychotomicznych swój/obcy oraz przyjaciel/wróg. A jednocześnie są znakomitym przykładem potwierdzającym przeświadczenie Stephena Greenblatta, że „wszyscy poruszamy się w polach reprezentacji właściwych naszym kulturom - konstytuujących je, a zarazem przez nie uwarunkowanych"43.

41. Pick, Czym jest transfer kultury?..., s. 256.

42. Dorota Kołodziejczyk, Postkolonialne odzyskiwanie pamięci: zawłaszczenia, fabulacje, niesamowite odpominanie, w: Od pamięci biodziedzicznej do postpamięci, red. Teresa Szostek, Roma Sendyka, Ryszard Nycz, Wydawnictwo Instytutu Badań Literackich PAN, Warszawa 2013, s. 289.

43. Prokop-Janiec, Etnopoetyka..., s. 189. 
